\title{
The Marginal Effects Of Consumer Characteristics On Internet Channel Choice
}

\author{
James Reardon, (Email: james.reardon@unco.edu), University of Northern Colorado \\ John Wicks, (Email: john.wicks@mso.umt.edu), University of Montana \\ Denny E. McCorkle, (Email: denny.mccorkle@unco.edu), University of Northern Colorado \\ Douglas Dalenberg, (Email: doug.dalenberg@mso.umt.edu), University of Montana
}

\begin{abstract}
Multiple retail channels (e.g., retail stores and catalogs) have been available to consumers for more than a century, while consumer decision making and academic research focused on channel choice with regard to the Internet is limited. This research integrates and adapts relevant literatures to develop a model of channel choice based on demographics and for the first time explicitly measures consumer switching propensities between channels. The findings suggest that consumers with Internet access tend to switch from traditional direct response retailing to the Internet and that time pressured consumers tend to switch from physical retail stores to the Internet and vice versa for older consumers. Strategic implications are also provided.
\end{abstract}

\section{INTRODUCTION}

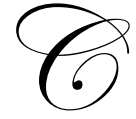

onsumers' choice of retail channels has grown tremendously in the past decade. The traditional physical store is now in competition with at least eight non-traditional retail channels available for consumers (O'Cass and Fenech 2002), including non-physical or virtual stores such as found at web sites on the Internet, shopping channels on television, direct mail catalogs, and elsewhere.

Of the alternatives to physical stores, the growth of the Internet has been the most explosive, as:

- Internet usage continues to grow as the number of active home Internet users in the U.S. as of January 2006 was 143.4 million (Neilson/Netratings 2006);

- Internet purchasing is increasing as first quarter online sales for 2006 were $\$ 25.2$ billion, up 7 percent from the fourth quarter of 2005 (U.S. Census Bureau 2006); and

- Internet commerce currently represents $2.6 \%$ of total retail sales with an annual growth rate that is more than 3 times that of total retail sales, $25.4 \%$ versus $8.1 \%$ respectively (U.S. Census Bureau 2006).

The contribution of this research is threefold. First, a conceptual framework to understand the demographic effects on consumer channel choice is developed. Second, the framework is developed into an empirical model and tested. Finally, the marginal effects of these demographics on channel choice are calculated and discussed.

\section{LITERATURE REVIEW AND HYPOTHESES DEVELOPMENT}

Common to several models of store choice is the idea that choice is based on the consumer characteristics. Many of the empirical effects of demographics on channel choice have been well documented. However, the logic as to why these effects exist is often limited. Using the current state of literature and often supposition based on logic, the authors develop a set of hypotheses as to why consumer characteristics affect channel choice.

Research has indicated that the higher a consumer's socio-economic status (i.e., education, income, occupation), the greater likelihood for non-store shopping. The logic is that those with a greater socio-economic status would have: (1) more resources such as income to shop for higher value products and services as often sold by 
non-store channels such as catalogs and web sites (Darian 1987; Donthu and Garcia 1999); (2) less resources such as time and thus would seek out more convenient ways to shop (Cotte, Chowdhury, Ratneshwar, and Ricci 2006), (3) more education and knowledge of the available channel choices (Darian 1987; Donthu and Garcia 1999; Assael 2005); and (4) greater access to the available channels (e.g., computer and Internet access; targeted by catalogers and other direct response marketers). Hypotheses for each of these demographic variables are developed as follows.

\section{Channel Access}

Obviously, the ability to access to a particular channel is needed before it can be considered as a viable channel choice. For example, in order to consider a physical store as a channel choice, the consumer will need transportation to get to the store. Likewise, in order to consider the Internet as a channel choice, Internet access at home or work is needed. In fact, it is with the fundamental expansion of access to the Internet that retail channel choice has changed and needs further research. Industry research indicates that longer time users of the Internet are also more likely to use the Internet for buying products and services (Kerner 2004).

H1: Consumers with home Internet access will more likely buy products via the Internet than from other channels.

\section{Time Scarcity}

Time availability has been found as an important predictor of store and channel choice (Darian 1987; Eastlick and Feinberg 1994). Kelley, Donnelly, and Skinner (1990) suggest that consumers act as partial employees by participating in the transaction process at the retail level. The degree to which they are willing to provide time and energy as a tradeoff for value is, in part, determined by resource availability. Consumers with less time are more likely to shop via channels that require minimal time regardless of small price increases. In the traditional retail environment, this is best typified by convenience stores.

In the channel choice decision, direct response channels, including the Internet, are most often cited as being used for convenience. Customers often cite convenience as being the primary motivation for using the Internet (Greenspan 2003). From the earlier studies of catalog to current studies of the Internet shopping, convenience is most often identified as a primary motivation of channel/store choice (Raijas 2002; Sim and Koi 2002). Korgaonkar (1984) found that convenience oriented shoppers would more likely use non-store alternatives; and Gehrt and Carter (1992) found that catalog shoppers could be described as convenience oriented or recreational oriented. More recently, other researchers have also found the connection between time (Cotte, Chowdhury, Ratneshwar, and Ricci 2006) or convenience (Jarvenpaa and Todd 1997; Donthu and Garcia 1999; Szymanski and Hise 2000; Chiang and Dholakia 2003; Rohm and Swaminathan 2004) and Internet shopping/buying behavior.

A consumer can save shopping time by using the Internet to comparison shop and better educate themselves to product, brand, store, and channel choices. Alternatively, that same consumer can save time by seeking the convenience of shopping and buying from their favorite direct response catalogs or web retailers. Therefore, based on the increasing pressures of time and needs for convenience, the authors hypothesize that:

H2: Time scarce consumers will more likely buy products via the Internet than from other channels.

\section{Education}

Better educated consumers are most likely to have the most developed knowledge and human capital available. Education implies a broader array of knowledge and skill for accessing information concerning products, brands, stores, and channels. Indeed, formal education most often includes instruction on information access through the Internet and other research tools. The basic knowledge and familiarity (e.g., comfort level) with these tools is likely to lead to their extended use for shopping. 
Evidence in the in-home shopping literature was found by Berkowitz, Walton, and Walker (1979) and Darian (1987) that in-home shoppers had higher than average education and occupation levels than physical store shoppers. More specific to the Internet and even though hypothesized as otherwise, Donthu and Garcia (1999) and Dholakia and Uusitalo (2002) both found that Internet shoppers did not differ significantly from Internet nonshoppers on education. Others have further explained such unexpected results as due to the changing demographic profile of the Internet store shopper to look more like the average physical store shopper. Nonetheless, some results have shown that Internet shoppers are more educated than non-Internet shoppers (Vijayasarathy 2003), heavy Internet shoppers are more educated than other Internet shoppers (Assael 2005), and that the convenience of Internet shopping is a greater motivator at higher levels of education and income (Swaminathan, Lepkowska-White, and Rao 1999). For the latter reasons, the authors hypothesize that:

H3: Higher educated consumers will more likely buy products via the Internet than from other channels.

\section{Income}

As indicated by Darian (1987) and Danthu and Garcia (1999), one of the fundamental reasons for higher income consumers to use the Internet is their ability to shop for specialized products not typically available in the local market. These might include one-of-a-kind products that only exist in a specialized market (e.g., one-of-a-kind items on e-bay, or from high-end specialty stores in other geographic markets).

In addition to specialized or opportunistic buying, higher income consumers tend to suffer less financial risk in any given purchase situation. Particularly with regards to financial risk, the degree or amount of risk is determined by income. For example, an individual with a $\$ 100,000$ income would likely see a lower risk in purchasing a television set than a student with a minimal disposable income; and this higher income person would also be less concerned with the risk of a channel choice for making this purchase.

The concept of risk or uncertainty has been applied to a consumer's choice of products (Campbell and Goodstein 2001), brands (Erdem 1998), and stores (Dash, Schiffman, and Berenson 1976). Since it has been suggested that the risk of a product is transferable to the store or source that sells the product (Spence, Engel, and Blackwell 1970; Hisrich, Dornapf, and Kernan 1972; Prasad 1975), this concept can be extended to the channel choice. Indeed, there is ample research providing evidence that non-store shopping results in higher perceived risks than with physical store shopping (Cox and Rich 1964; Spence, Engel, and Blackwell 1970; Festervand, Snyder and Tsalikis 1986; Hawes and Lumpkin 1986; Van den Poel and Leunis 1996) and that certain types of risk are greater with Internet shopping than with physical store shopping (Novak, Hoffman, and Yung 2000; Mayer, Davis, and Schoorman 1995; Lee and Turban 2001). Thus, as risk for a given channel increase, consumers with higher incomes are more likely to be able and willing to bear this risk.

More specific to influence of income on channel choice, Darian (1987) found that households in the middle income groups were more likely to be in-home shoppers; and higher incomes were among the most consistent findings in the early academic research to distinguish in-home shoppers from non in-home shoppers (McCorkle, Planchon, and James 1987). More current research specific to the Internet has also carried forward this hypothesis (Donthu and Garcia 1999; Dholakia and Uusitalo 2003; Vijayasarathy 2003), with the research of Swaminathan, LepkowskaWhite, and Rao (1999) connecting the Internet shopping motivation of convenience as positively related to higher levels of education and income. Additionally, Assael (2005) found that among Internet users, the heavy users were more likely to have household incomes of $\$ 100,000$ to $\$ 150,000$.

The in-home shopping and Internet research literature, along with the connections to risk and convenience lead the authors to hypothesize that:

H4: Higher income consumers will more likely buy products via the Internet than from other channels. 
Age

Research has indicated that consumer innovativeness is higher among younger consumers (Steenkamp, ter Hofstede, and Wedel 1999; Venkataram and Price 1990). While the literature looks more to the younger innovators as seeking out new products, services, brands, stores and other innovative experiences, this innovative behavior can also be applied to channel choice. As the newest channel for shopping and buying products and services, the Internet also presents itself as the newest technology for gathering information, communicating, and as a tool for work or home. Given the relative propensity of younger consumer to seek novelty, logic dictates that they are more likely to adopt the Internet channel. In addition, younger consumers have had more access and familiarity, both through formal education and informal use of the Internet. Alternatively, older generations face a steep learning curve to gain access to the Internet, with some not as familiar with how to use the prerequisite tools (e.g., mouse and keyboard) to access the Internet.

Besides the logical explanation presented above, there is limited literature to support the relationship between younger consumers and newer and innovative channels. Younger shoppers have been found to have more positive perceptions (Dholakia and Uusitalo 2003) and intentions (Vijayasarathy 2003) to use the Internet for shopping than older shoppers. Also, a more recent study found that the likelihood of being a heavy Internet user decreases with increasing age, and more specifically that these heavy Internet users were 40 percent more likely than non-heavy Internet users to be 18-34 in age (Assael 2005). In another more recent study, Sorce, Perotti, and Widrick (2005) found that even though their sample of older online shoppers purchased as much as did the younger online shoppers, age explained more variance in purchasing behavior if the product was first searched for online.

Therefore, based on supporting literature and the newness and innovativeness of the Internet as an alternative channel, the authors hypothesize that:

H5: Younger consumers will more likely buy products via the Internet than from other channels.

\section{METHODOLOGY}

\section{Model}

Consider a shopper who has decided to purchase a specific product. The shopper now faces multiple Channel Choices $\left(\mathrm{CC}_{\mathrm{i}}\right)$. The shoppers' characteristics determine, in part, this choice (Char $\left.{ }^{\mathrm{CCi}}\right)$ for each channel. Hence, this is referred to as the random utility model (c.f., Baltas and Doyle 2001 for an excellent review). Assuming that the errors are independent and identically distributed double exponential random errors, the probability that a shopper chooses a particular channel option is:

$\operatorname{Prob}^{\mathrm{CCi}}=\mathrm{Char}^{\mathrm{CCi}} / \sum_{\mathrm{i}} \mathrm{Char}^{\mathrm{CCi}}$.

As consumer characteristics favoring one channel increase, the probability of the consumer to choose that channel increases, while the probability of channel choice for all other channels decrease.

Inherent in the discussion of store choice models is the ability of consumers to obtain their ideal bundle of goods while minimizing cost and effort. While certainly important, in this research the authors utilize the traditional assumption of a single purchase for matters of simplification. Incorporating multi-item, multi-stop purchases into the proposed model is a matter of simple extension once this research is complete.

\section{Pretest}

In order to apply this model, the authors sought to identify those products that: (1) held a commodity-like status in the eyes of the consumer (i.e., a product from one channel is identical to that from another); (2) were widely available over several channels; and (3) were widely purchased items. A process of elimination led to five products: (1) music compact discs (2) movies on VHS; (3) movies on DVD; (4) best seller paperback books, and (5) best seller 
hardback books. All of these products are readily available in physical stores. A quick Google ${ }^{\circledR}$ search confirms that all of these items are widely available for purchase through the Internet. Also, these products are available in alternative channels, such as in the catalogs for music, movie or book clubs, and on television as special collections or limited/advance releases (e.g., Time-Life books; compact disk not yet available in stores).

In order to pre-test the measurement methods as well as the incidence of purchase of the five products across multiple channels an initial survey was developed. A convenience sample of 38 respondents from the general population was surveyed. The pretest results indicated the necessity of collapsing the original number of multiple retail channels into three: Physical Retail Store (Store), Internet Store (Internet), and Traditional Direct Response Channel (TradDM) (i.e., Catalogs, Direct Mail, Book Clubs, CD clubs, Magazine, Newspaper, Television, or Radio). In each channel, there were estimated to be sufficient incidence of purchase of each of the three product categories to continue. In addition, minor wording and question flow changes were made to assist the respondents' understanding.

\section{Functional Form}

Intuitively, estimation can be thought of as forming an index and calculating a probability for each channel based on the size of the index relative to the sum of all indices. For each channel CCi where i goes from 1 to 3 representing the three channels, the index can be written as:

Index ${ }_{i}=\beta_{0}+\beta_{\text {age }}{ }^{\mathrm{CCi}} \mathrm{Age}^{\mathrm{CCi}}+\beta_{\mathrm{Inc}}{ }^{\mathrm{CCi}}$ Income $^{\mathrm{CCi}}+\beta_{\mathrm{Gen}}{ }^{\mathrm{CCi}} \mathrm{Gender}^{\mathrm{CCi}}+\beta_{\mathrm{Mar}}{ }^{\mathrm{CCi}}$ Married $^{\mathrm{CCi}}+\beta_{\text {edu }}{ }^{\mathrm{CCi}}$ Education ${ }^{\mathrm{CCi}}+\beta_{\mathrm{ts}}{ }^{\mathrm{CCi}}$ TimeScarce ${ }^{\mathrm{CCi}}+\beta_{\text {Internet }}{ }^{\mathrm{CCi}}$ InternetAccess ${ }^{\mathrm{CCi}}+\delta_{\mathrm{vhs}} \mathrm{VHS}^{\mathrm{CCi}}+\delta_{\mathrm{pb}}$ PaperBack $^{\mathrm{CCi}}+\delta_{\mathrm{hb}} \operatorname{HardBack}^{\mathrm{CCi}}+\delta_{\mathrm{dvd}} \mathrm{DVD}^{\mathrm{CCi}}+\mathrm{e}$

Then the index is converted into a probability for each channel:

$\operatorname{Prob}^{\mathrm{CCi}}=e^{\mathrm{index} \mathrm{i}} / \sum_{\mathrm{i}} e^{\text {index I }}$,

thus resembling a traditional multinomial logistic function. Marital status and gender are included as covariates to avoid model under-specification.

\section{Sample}

A quota sample of 500 people was gathered in a Northwest MSA as delineated by the Census of Population. Census data provided the population within each of 14 "neighborhoods" comprising the area. The portion of the urban area population residing in each neighborhood determined the number of interviews in each. The intra-neighborhood randomization process involved first randomly placing as many pins in a map of the neighborhoods as there were needed interviews. The interviewer proceeded to the location indicated by a pin and then to a predetermined direction (e.g. approximately north from the first pinhole, south from the second, etc.) to interview a willing adult at the first residence encountered where such an adult was present. After conducting that survey, the interviewer went to the location of the next pinpoint on the map and repeated the process. The sample characteristics are shown in Table 1.

Table 1

Demographic Data

\begin{tabular}{|c|c|c|c|}
\hline & Current Sample & $\begin{array}{c}\text { Sample County* } \\
\text { 2000 Census Data }\end{array}$ & $\begin{array}{c}\text { United States* } \\
\text { 2000 Census Data }\end{array}$ \\
\hline N or population & 500 & 96,303 & $281,421,906$ \\
\hline Percent male & $49 \%$ & $50 \%$ & $49 \%$ \\
\hline $\begin{array}{c}\text { Percent High School } \\
\text { Graduate (age 25 and over) }\end{array}$ & $98 \%$ & $91 \%$ & $80 \%$ \\
\hline $\begin{array}{c}\text { Percent College Graduate } \\
\text { (age 25 and over) }\end{array}$ & $43.3 \%$ & $32.8 \%$ & $24.4 \%$ \\
\hline Married & $44.4 \%$ & $50.6 \%$ & \\
\hline
\end{tabular}

* Source: U.S. Bureau of the Census, http://quickfacts.census.gov/qfd/index, viewed 2/12/04. 


\section{Measures}

Product And Channel. Each respondent was queried on which of the five products most recently was purchased in the last six months and from which of the three channels. The interview continued focusing on the specified product and channel.

Consumer Characteristics. Consumer characteristics were measured using readily available demographic measures, as indicated in the model and hypotheses. These included: Age, Income, Gender, Marital Status, and Years Education.

Internet Access. The major capital constraint faced by consumers is home Internet access. Included was a variable (INTERNET ACCESS) to measure this, with a " 1 " if the consumer had access to a home Internet connection for shopping and " 0 " otherwise.

Time Scarcity. Consumer time can be conveniently divided into four major activities, work, leisure, bodily maintenance, and household production. Since leisure, bodily maintenance, and household production tend to be flexible (i.e., non-restrictive as to time period or length), they present minimal constraints on an individual's time. Working time, for most, is restrictive in period, length, and structure. Thus it presents a significant restriction and is adopted as a surrogate for total time constraints.

\section{Descriptive Statistics}

The sample yielded 500 observations. Table 2 presents the mean values for the sample and for each channel.

Table 2

Descriptive Statistics

\begin{tabular}{|c|c|c|c|c|}
\hline & Total & Store & Internet & Direct. Response \\
\hline $\mathrm{N}$ & 500 & 153 & 178 & 169 \\
\hline Age & 34.0 & 36.7 & 30.7 & 35.2 \\
\hline Gender & 0.51 & 0.52 & 0.52 & 0.49 \\
\hline Married & 0.44 & 0.48 & 0.36 & 0.50 \\
\hline Education & 14.3 & 14.6 & 14.3 & 14.2 \\
\hline Work hours & 23.1 & 19.5 & 26.4 & 22.9 \\
\hline Weekly Pay & 321.81 & 310.31 & 334.06 & 319.32 \\
\hline Internet Access & $84.2 \%$ & $83.0 \%$ & $96.6 \%$ & $72.2 \%$ \\
\hline CD & $31.4 \%$ & $26.1 \%$ & $32.0 \%$ & $35.5 \%$ \\
\hline Paperback & $16.2 \%$ & $18.9 \%$ & $15.1 \%$ & $14.8 \%$ \\
\hline Hardback & $17.4 \%$ & $17.0 \%$ & $16.2 \%$ & $18.9 \%$ \\
\hline DVD & $23.0 \%$ & $18.3 \%$ & $30.3 \%$ & $19.5 \%$ \\
\hline VHS & $12.0 \%$ & $19.6 \%$ & $6.2 \%$ & $11.2 \%$ \\
\hline
\end{tabular}

\section{Marginal Effects}

The coefficients of a multinomial logistic regression cannot be directly interpreted due to the functional form. To correct this and test the hypotheses, the marginal effects were calculated. Following Greene (2000), the marginal effects at the mean of the other variables were calculated and the proper corrections for interpretation of categorical independent variables were made. Given the assumption that the decision to make a purchase is assumed $a$ priori, a person must choose one of the three channels. Thus, any increase in the probability of choosing one channel must come at the expense of the other channels so that the total probability adds to 100 percent. Marginal effects quantify effects of marginal changes in characteristics of an average consumer on the probability that they shop in a given channel. 


\section{RESULTS AND DISCUSSION}

A multinomial logistic model with channel choice being the dependent variable and individual characteristics as the independent variables performs the required estimation from which the marginal effects can be calculated.

\section{Model Fit}

The model fits reasonably well, as shown in Table 3 .

Table 3

Goodness of Fit Comparisons

\begin{tabular}{|c|c|}
\hline & Measure \\
\hline Cox and Snell R-Squared & .18 \\
\hline Nagelkerke R-Squared & .20 \\
\hline McFadden R-Squared & .09 \\
\hline Model Chi Squared & $98.1(\mathrm{p}<.0001)$ \\
\hline Predicted Correctly - Traditional Retailer & $52 / 153=34 \%$ \\
\hline Predicted Correctly - Internet Store & $127 / 178=71 \%$ \\
\hline Predicted Correctly - Traditional Direct Response & $62 / 169=37 \%$ \\
\hline
\end{tabular}

\section{Tests Of Hypotheses}

LIMPDEP 7.0 was used to calculate the multinomial logistic model. The model uses the traditional retail store as the base from which the others are measured.

Table 4

Multinomial Logit Estimates

\begin{tabular}{|c|c|c|}
\hline & \multicolumn{2}{|c|}{$\begin{array}{c}\text { Channel Relative to Physical Store } \\
\text { Coefficients and (asymptotic t statistics) }\end{array}$} \\
\hline & Internet & Direct Response \\
\hline Constant & $1.33,(1.31)$ & $2.50 *,(2.76)$ \\
\hline Age & $-.03 *,(-2.52)$ & $-.02,(-1.81)$ \\
\hline Education & $-.12 *,(-2.12)$ & $-.07,(-1.30)$ \\
\hline Work Hours & $.03 *,(3.66)$ & $.02 *,(2.05)$ \\
\hline Weekly Pay & $-.0005,(-1.28)$ & $-.0004,(-0.98)$ \\
\hline Internet Access & $1.44 *,(2.86)$ & $-.92 *,(-2.84)$ \\
\hline Gender & $-.15,(-0.60)$ & $-.13,(-0.55)$ \\
\hline Married & $-.14,(-0.48)$ & $.27,(1.00)$ \\
\hline VHS tape & $-1.41 *,(-3.26)$ & $-1.11 *,(-2.95)$ \\
\hline Paperback book & $-.01,(-0.05)$ & $-.40,(-1.09)$ \\
\hline Hardback book & $.25,(0.68)$ & $-.01,(-0.03)$ \\
\hline DVD & $.17,(0.52)$ & $-.35,(-1.02)$ \\
\hline $\mathrm{N}$ & 500 & \\
\hline Log likelihood & -525.4 & \\
\hline
\end{tabular}

* statistically significant in a two-sided test at the 5 percent error level.

As discussed in the methodology, marginal effects were calculated to determine the propensity of consumers to use one channel over another based on their characteristics. 
Table 5

Marginal Effects Evaluated at the Means

\begin{tabular}{|c|c|c|c|c|}
\hline Hypothesis & Marginal Change & Store & Internet & $\begin{array}{c}\text { Direct } \\
\text { Response }\end{array}$ \\
\hline \multicolumn{2}{|c|}{ Baseline Share at the Mean } & $31.8 \%$ & $32.2 \%$ & $36.0 \%$ \\
\hline H1: Internet Access & $\begin{array}{c}\text { Effect of having an Internet } \\
\text { connection }\end{array}$ & $\begin{array}{l}-4.3 \% \\
(-0.59)\end{array}$ & $\begin{array}{l}+42.2 \\
(4.47 *)\end{array}$ & $\begin{array}{c}-37.9 \\
(-5.29 *)\end{array}$ \\
\hline H2: Time Scarcity & $\begin{array}{c}\text { Effect of } 10 \text { more hours of } \\
\text { work per week }\end{array}$ & $\begin{array}{c}-5.0 \% \\
(-3.27 *)\end{array}$ & $\begin{array}{c}+5.0 \\
(3.01 *)\end{array}$ & $\begin{array}{c}+0.0 \\
(.21)\end{array}$ \\
\hline H3: Education & Effect of 1 more year of educatior & $\begin{array}{l}+2.1 \% \\
(1.99 *)\end{array}$ & $\begin{array}{c}-1.9 \\
(-1.67 *) \\
\end{array}$ & $\begin{array}{c}-0.2 \\
(-0.19) \\
\end{array}$ \\
\hline H4: Income & $\begin{array}{c}\text { Effect of earning } 100 \text { more } \\
\text { dollars per week }\end{array}$ & $\begin{array}{r}1.0 \% \\
(1.34) \\
\end{array}$ & $\begin{array}{r}-1.0 \% \\
(-0.84)\end{array}$ & $\begin{array}{r}-0.0 \% \\
(-0.35)\end{array}$ \\
\hline H5: Age & $\begin{array}{c}\text { Effect of } 10 \text { year increase in } \\
\text { age }\end{array}$ & $\begin{array}{l}+\mathbf{5 . 0 \%} \\
(2.62 *)\end{array}$ & $\begin{array}{c}-5.0 \\
(-1.93 *)\end{array}$ & $\begin{array}{c}-0.0 \\
(-0.25)\end{array}$ \\
\hline
\end{tabular}

Note: Asymptotic t statistics are for marginal effects are calculated at the means and presented in the parentheses. Dummy variables marginal effects are estimated using the continuous formula. * statistically significant in a one-sided test at the 5 percent error level.

H1: Home Internet Access - Supported. As expected, home Internet access has a large impact on channel choice. Home Internet access increases the probability of using the Internet channel about 42 percent at the mean, primarily at the expense of traditional DR channels (38 percent lower probability). This result is largely intuitive and one would expect such a result with any channel access constraint. Further it appears that firms primarily using catalogs, print, and television DR may face serious future challenges as Internet access grows and people become more comfortable with online commerce. Interestingly, while the shift of about four percent occurred from traditional stores to the Internet, this variable was not significant. Thus, it is unknown if a shift occurs from traditional retail stores to the Internet as the amount of access increases.

H2: Time Scarcity - Supported. An increase in time pressure (i.e., working more hours per week) tends to shift the probability of purchases toward the Internet and away from physical stores. For each ten hours additional a person works, about a five percent shift in probability occurs. Thus, moving from a non-working status to a full time job would shift the probability of purchase from traditional retail stores to the Internet at about a 20 percent rate. Given the convenience of shopping without geographical boundaries via the Internet, this should be expected. As mentioned previously, convenience is often most cited as a primary reason or motivation for shopping via the Internet. Perhaps the most unexpected result here is the lack of an increase in the likelihood in shopping through traditional DR channels. This somewhat reinforces the notion from the first hypotheses that the Internet is most likely cannibalizing traditional DR sales, as one would expect time pressures to shift purchases from stores to traditional DR as well as the Internet.

H3: Education - Not Supported. The results of $\mathrm{H} 3$ are in direct contradiction to what one would expect given the literature and logic. The results suggest that for every additional year of education, the probability increases approximately two percent for shopping in traditional retail stores at the expense of shopping via the Internet. Most of the older studies indicate that traditional DR shoppers have a higher level of education, as compared to store shoppers (Berkowitz, Walton, and Walker, 1979; Darian 1987). However, Donthu and Garcia (1999) and Dholakia and Uusitalo (2002) both found that Internet shoppers did not differ significantly from Internet non-shoppers. It appears that once other variables are accounted for (e.g., time scarcity and age) the opposite of what is expected happens. The authors are at a loss to explain this finding - although certainly recommend further study to collaborate this effect or potentially identify it as an aberration.

H4: Income - Not Supported. As with education, it appears that increases in income do not increase one's propensity to shop online. Due to the results of earlier empirical studies of in-home shoppers, a higher income level was expected for Internet shoppers (McCorkle, Planchon, and James 1987). Perhaps consumers are seeing the two channels (Internet versus traditional retail) as more alike in their product availability. In the past, much of the 
traditional direct response shopping was for specialized products that typically cost more (e.g. clothing in specialty catalogs; Time-Life book sets from DR TV) and higher income shoppers were willing to pay more to get more. However, given the variety of products now available thru the Internet (i.e., both commodities and specialized), and the increasing number of web sites that exist to help consumers compare and find the best prices (fatwallet.com, mysimon.com ), the product choices and their prices are looking more alike and attracting consumers across all income groups. In addition, the products used to test this hypothesis were relatively inexpensive, thus potentially not posing a significant financial risk to any income level.

H5: Age - Supported. As expected, younger people tended to have a higher probability of shopping via the Internet versus traditional retail stores. In fact, for every 10 years of age, there appears to be about a five percent shift between channels. The most likely explanation for this is the familiarity of the Internet channel with the younger generation. Older consumers face a significant learning curve to adopt new technologies. This is not to suggest that older consumers do not or will not likely shop through the Internet, but rather the probability of older consumers continuing their current channel behavior tends to be more likely than for younger consumers. While this effect may become less pronounced over time, it is expected that as more innovative channel choices continue to develop, this same marginal effect of age for newer channel innovations will continue.

Interestingly, there was little marginal effect of age on the probability to shop through other traditional direct response channels. Potentially, these channels are more likely affected by consumer characteristics other than age.

\section{IMPLICATIONS AND CONCLUSIONS}

The strategic implications of these results are important to all retailers. First, the results suggest that consumers can be effectively segmented for channel choice based on easily available demographic information. The results found that Internet access, time scarcity, and age were significant predictors of channel choice (refer to H1, H2, H5). However, one should be careful in interpreting these results. For example, from the results one might assume a retailer selling geriatric products has no business being on the Internet. Such an interpretation might be completely wrong since the results do not indicate that older people do not buy via the Internet, but only that they tend to have a higher probability of buying in traditional retail stores relative to younger shoppers. Thus, it would be much safer to conclude that such a retailer might first develop a traditional retail presence, and then look at the marginal cost/benefits of developing an Internet channel. The same is especially true for younger customers. The results do not indicate a lack of the younger consumers buying via traditional retail stores, only a higher probability that older people will purchase the researched product types (e.g., CD's, books, movies) via the Internet.

Second, for retailers of any channel, multi-channel retailing is imperative for the future. The research results support the notion that traditional stores and traditional direct response channels could lose sales to the Internet channel. As more consumers connect to the Internet and use it for obtaining product, store, and channel information, the greater the likelihood that they will also use it for shopping, particularly when they are more pressed for time and desiring convenience (refer to $\mathrm{H} 1$ and $\mathrm{H} 2$ ). At a minimum, traditional physical stores and traditional direct response channels need an Internet presence to provide their targeted consumers the opportunity to find them when comparison or research shopping. Perhaps equally or more important, is for the more traditional channels to provide an opportunity and the convenience of purchasing on their web site, too.

Third, these results also suggest that the demise of the retail store may be somewhat overstated. It appears that as people gain access to the Internet, it is not so much the traditional retail store that suffers, but rather other direct response retailers. Thus, those customers already willing to shop/buy from a non-physical or direct response retailer, may prefer the Internet for ordering due to its added convenience over other traditional direct response channels (refer to H2). This may be due to the slower direct mail ordering process or the sometimes bothersome telephone ordering process used by the traditional direct response channels. When a potential customer has questions, the traditional phone ordering method may win out, but when that same consumer knows exactly what to purchase, the Internet may provide an easier ordering process, and for repeat customers, a quicker ordering process, too. 
Fourth, there are implications for the retail mix of retailers, especially those such as department stores that may cater to a diversely aged target market. Such a multi-channel retailer should focus the orientation (design, merchandising, etc.) of a physical store slightly differently than their Internet site. Obviously a retailer wants to portray a single/uniform image across multiple channels if branded with the same name, but minor changes in the retail mix may have greater impact.

Location/Access. With increasing numbers of all ages using the Internet for comparison shopping and buying, physical retailers need to add e-commerce functions to remain competitive, especially with the younger (H5) and time scarce (H2) consumers. These consumers will likely begin their shopping with the Internet, while others in the target will rely more on the physical store. Also, if not actively doing so, any retailer with a catalog should make it easy for their catalog customers to shop and compare with the catalog, but complete their purchasing online (H1). Integration of these diverse channels is an important multi-channel strategy.

Merchandise Mix. Since a younger aged shopper is more likely to use the Internet channel (H5), an expanded selection and a slightly younger feel or more trendy merchandise should be provided there than thru the physical store. Also, a multi-channel marketer should provide more detailed information about the products (sizing, color choices, quality levels, etc.) because the Internet shopper is often there for time savings. Just as a good physical retail salesperson can do suggestive selling to encourage their customers toward impulse purchases (such as upgrades or add-ons), such cross-selling opportunities should be made available thru the Internet channel, too.

Communication. Younger (H5) and more time scarce (H2) customers in a retailer's target market are likely more attentive to online advertising and promotions, while the older customers with lower levels of Internet access and shopping/buying experiences will respond more to the traditional print and television communications. Thus, developing, maintaining, and utilizing a database would be an important communications strategy, especially one that centers on e-mail/newsletter communication providing how-to and newsworthy information about the retailer, it's multiple channels, it's new merchandise, how-to judge and compare quality from a distance, etc. Other online media such as search engine and online advertising should also be used to inform and remind the current and potential younger and time scarce customers of their multi-channel purchase options. More expensive direct response materials such as catalogs, post cards, and other direct mail should only be sent to those customers requesting receipt or with a proven response thru that particular channel. Communication with a database as the central point will be of extreme importance for an integrated multi-channel strategy.

Pricing. Multi-channel strategies in this area will depend upon a retailer's brand image, quality level, and competition. While the time scarce customers (H2) may be willing to pay more for the convenience of online or direct response shopping, other customers will be much more price sensitive, use the Internet for comparison shopping, and may demonstrate minimal loyalty to any one retailer. Strategically, offering exclusive or limited availability brands, private-label brands, or value added conveniences or services will be more profitable than trying to match or beat the best price for the same products or services available from numerous discount-oriented competitors.

Service Mix. Personal services will be important in this area. If the older aged customer (H5) from a retailer's target market is more likely to shop in the store, then more strategic attention should be given to this demographic, such as similarly aged sales people. However, since convenience is important for many Internet shoppers (H2), time saving services should be more of the focus for the Internet channel (e.g., easy registration, quick comparisons, product review summaries, live chat, easy checkout and payment, etc.).

Lastly, the research addresses and questions several long-held stereotypes about shopping. Although this research needs additional validation to examine under what conditions it applies, the traditional stereotypes for gender, marital status, education, and income seem absent.

\section{SUGGESTIONS FOR FUTURE RESEARCH}

Literature and logic were used to hypothesize the effect of consumer characteristics on channel choice. Some of the literature implies theoretical support for direct cognitive/affective effects. While consumer characteristics tend 
to mirror these cognitive/affective conditions (e.g., higher income denotes lower financial risk for any purchase), it should be considered to test these effects (e.g., risk perceptions) directly. While theoretically favorable to directly test cognitive/affective effects, the practical utility of the results decline (i.e., it is more difficult to develop strategy from unobservable cognitive/affective variables).

This study extends the external validity beyond a single product by using five products. However, all of these products would fall into a relatively narrow category (i.e., entertainment products). Moving beyond simple commodities presents significant challenges in both measurement and additional determinants (e.g., unique products; products or services not available in retail stores).

While restrictive in only examining the effects of demographics on channel choice, this research adds the use of marginal analysis to measure and examine the switching propensities between channels. Further use of this improved methodology is needed to examine the complexities of channel choice and improved insight for marketing strategies. While the current model and methodology provides needed information and a base from which to further examine the issue of channel choice, more research is needed.

\section{REFERENCES}

1. Assael, Henry, (2005), A Demographic and Psychographic Profile of Heavy Internet Users and Users by Type of Internet Usage, Journal of Advertising Research, (March), 93-123.

2. Baltas, George and Peter Doyle, (2001), Random Utility Models in Marketing Research: A Survey, Journal of Business Research, 51 (2), 115-125.

3. Berkowitz, Eric N., John R. Walton, and Orvile C. Walker, Jr., (1979), In-Home Shopper: The Market for Innovative Distribution Systems, Journal of Retailing, 55 (3), 15-33.

4. Campbell, Margaret C. and Ronald C. Goodstein, (2001), The Moderating Effect of Perceived Risk on Consumers' Evaluations of Product Incongruity: Preference for the Norm, Journal of Consumer Research, 28 (December), 439449.

5. Chiang, Kuan-Pin and Ruby Roy Dholakia, (2003), Factors Driving Consumer Intentions to Shop Online: An Empirical Investigation, Journal of Consumer Psychology, 13 (1/2), 177-183.

6. Cotte, June, Tilottama G. Chowdhury, S. Ratneshwar, and Lisa M. Ricci, (2006), Pleasure or Utility? Time Planning Style and Web Usage Behaviors, Journal of Interactive Marketing, 20 (Winter), 45-57.

7. Cox, Donald F. and Stuart U. Rich, (1964), Perceived Risk and Consumer Decision Making-The Case of Telephone Shopping, Journal of Marketing Research, 1 (November), 32-39.

8. Darian, J. C., (1987), In-home Shopping: Are There Consumer Segments? Journal of Retailing, 63 (2), 163-186.

9. Dash, J. F., L. G. Schiffman, and C. Berenson, (1976), Risk and Personality-Related Dimensions of Store Choice, Journal of Marketing, 40 (1), 32-39.

10. Dholakia, Ruby Roy and Outi Uusitalo, (2002), Switching to Electronic Stores: Consumer Characteristics and the Perception of Shopping Benefits, International Journal of Retail \& Distribution Management, 30 (10), 459-469.

11. Donthu, N. and A. Garcia, (1999), The Internet Shopper, Journal of Advertising Research, (May/June), 52-58.

12. Eastlick, M. and R. Feinberg, (1994), "Gender Differences in Mail-Catalog Patronage Motives," Journal of Direct Marketing, 8 (2), 37-44.

13. Erdem, Tulin, (1998), “An Empirical Analysis of Umbrella Branding,” Journal of Marketing Research, 35 (August), 339-351.

14. Festervand, Troy A., Don R. Snyder, and John D. Tsalikis, (1986), Influence of Catalog vs. Store Shopping and Prior Satisfaction on Perceived Risk, Journal of the Academy of Marketing Science, 14 (Winter), 28-36.

15. Gehrt, K. C. and K. Carter, (1992), An Exploratory Assessment of Catalogue Shopping Orientations, Journal of Direct Marketing, 6 (1), 29-39.

16. Greene, William H., (2000), Econometric Analysis, New Jersey: Prentice Hall Publishing Company, fourth edition.

17. Greenspan, Robyn, (2003), E-tailers Will See Green, Clickz Stats, (November 6), <http://www.clickz.com/stats/sectors/retailing/article.php/6061_3105491>, downloaded March 14, 2005.

18. Hawes, Jon M. and James R. Lumpkin, (1986), Perceived Risk and the Selection of a Retail Patronage Mode, Journal of the Academy of Marketing Science, 14, (Winter), 37-42.

19. Hisrich, Robert D., Ronald J. Dornapf, and Jerome B. Kernan, (1972), Perceived Risk in Store Selection, Journal of Marketing Research, 9 (November), 435-439. 
20. Jarvenpaa, Sirkka L. and Peter A. Todd, (1997), Is There a Future for Retailing on the Internet? In Electronic Marketing and the Consumer. Ed. Robert A. Peterson. Thousand Oaks, CA: Sage. 139-154.

21. Kelley, S. W., J. H. Donnelly, Jr., and S. J. Skinner, (1990), Customer Participation in Service Production and Delivery, Journal of Retailing, 66 (3), 315-335.

22. Kerner, Sean Michael, (2004), More Broadband Usage Means More Online Spending, Clickz. Stats, (October 8), <http://www.clickz.com/stats/sectors/broadband/article.php/3419281>, downloaded March 14, 2005.

23. Korgaonkar, Pradeep. K., (1984), Consumer Shopping Orientations, Non-store Retailers, and Consumers' Patronage Intentions: A Multivariate Investigation, Journal of the Academy of Marketing Science, 12 (1), 11-22.

24. Lee, M.K.O. and E. Turban, (2001), A Trust Model for Consumer Internet Shopping, International Journal of Electronic Commerce, 6 (4), 75-91.

25. McCorkle, Denny E., John M. Planchon, and William L. James, (1987), In-Home Shopping: A Critical Review and Research Agenda, Journal of Direct Marketing, 1 (Spring), 5-21.

26. Mayer, R.C., J.H. Davis, and D.F. Schoorman, (1995), An Integrative Model of Organizational Trust, Academy of Management Review, 20 (3), 709-734.

27. Neilson/NetRatings, (2006), United States: Average Web Usage, NetView Usage Metrics, http://www.nielsennetratings.com/news.jsp?section=dat to\&country=us, downloaded February 12, 2006.

28. Novak, T. P., D.L. Hoffman, and Y.F. Yung, (2000), Measuring the Customer Experience in Online Environments: A Structural Modeling Approach, Marketing Science, 19 (1), 22-42.

29. O'Cass, Aron and Tino Fenech, (2002), Web Retailing Adoption: Exploring the Nature of Internet Users Web Retailing Behavior, Journal of Retailing and Consumer Services, 10 (2), 81-94.

30. Prasad, V. Kanti, (1975), Socioeconomic Product Risk and Patronage Preferences of Retail Shoppers, Journal of Marketing, 39 (July), 42-47.

31. Raijas, A., (2002), The Consumer Benefits and Problems in the Electronic Grocery Store, Journal of Retailing and Consumer Services, 9 (2), 107-113.

32. Rohm, Andrew J. and Vanitha Swaminathan, (2004), A Typology Of Online Shoppers Based On Shopping Motivations, Journal of Business Research, 57 (7), 748-757.

33. Sim, L.L. and S.M. Koi, (2002), Singapore's Internet Shoppers and Their Impact on Traditional Shopping Patterns, Journal of Retailing and Consumer Services, 9 (2), 115-124.

34. Sorce, Patricia, Victor Perotti, and Stanley Widrick, (2005), Attitude and Age Differences in Online Buying, International Journal of Retail \& Distribution Management, 33 (2), 122-132.

35. Spence, Homer E., James F. Engel, and Roger D. Blackwell, (1970), Perceived Risk in Mail Order and Retail Store Buying, Journal of Marketing Research, 7 (August), 364-369.

36. Steenkamp, J-B.E.M., F. ter Hofstede, and M. Wedel, (1999), A Cross-National Investigation into the Individual and National Cultural Antecedents of Consumer Innovativeness, Journal of Marketing, (63), 55-69.

37. Swaminathan, Vanitha, Elzbieta Lepkowska-White, and Bjarat P. Rao, (1999), Browsers or Buyers in Cyberspace? An Investigation of Factors Influencing Electronic Exchange, Journal of Computer Mediated Communication, Vol. 5 (December), http://www.ascusc.org/jcmc/vol5/issue2/swaminathan.htm, downloaded July 29, 2004.

38. Szymanski, David M. and Richard T. Hise, (2000), e-Satisfaction: An Initial Examination, Journal of Retailing, 76 (Fall), 309-322.

39. U.S. Census Bureau, (2006), Quarterly Retail e-Commerce Sales 1st Quarter 2006, U.S. Census Bureau News, (May 18), http://www.census.gov/mrts/www/data/html/06Q1.html, downloaded June 8, 2006.

40. U.S. Census Bureau, (2000), State \& County QuickFacts, (April 1),

41. http://quickfacts.census.gov/qfd/index, downloaded February 12, 2004.

42. Van den Poel, Dirk and Joseph Leunis, (1996), "Perceived Risk and Risk Reduction Strategies in Mail-Order Versus Retail Store Buying," The International Review of Retail, Distribution and Consumer Research, 6 (October), 351-371.

43. Venkataram, M.P., and L.L. Price, (1990), Differentiating Between Cognitive and Sensory Innovativeness: Concepts, Measurement, and Implications, Journal of Business Research, (20), 293-315.

44. Vijayasarathy, Leo R., (2003), Shopping Orientations, Product Types and Internet Shopping Intentions, Electronic Markets, 13 (1), 67-79. 